NBER WORKING PAPER SERIES

\title{
IS THERE AN EFFECT OF INCREMENTAL WELFARE BENEFITS ON FERTILITY BEHAVIOR? A LOOK AT THE FAMILY CAP
}

\author{
Melissa Schettini Kearney \\ Working Paper 9093 \\ http://www.nber.org/papers/w9093 \\ NATIONAL BUREAU OF ECONOMIC RESEARCH \\ 1050 Massachusetts Avenue \\ Cambridge, MA 02138 \\ August 2002
}

The author thanks Joshua Angrist, David Autor, Amy Finkelstein, Jonathan Gruber, Jonathan Guryan, Phil Levine, Sean May, Sendhil Mullainathan, Diane Whitmore, and participants of the MIT labor and public finance lunches for helpful comments. She also thanks Bob Schoeni, Phil Levine, and Diane Whitmore for sharing CEA welfare policy data. Three anonymous referees provided thoughtful comments and suggestions. The National Science Foundation provided financial support through a Graduate Research Fellowship. The analyses, interpretations, and conclusions of this paper are attributable to the author, and not to the National Center for Health Statistics, which is responsible only for the initial natality data. The views expressed herein are those of the author and not necessarily those of the National Bureau of Economic Research.

(C) 2002 by Melissa Schettini Kearney. All rights reserved. Short sections of text, not to exceed two paragraphs, may be quoted without explicit permission provided that full credit, including $(\subset$ notice, is given to the source. 
Is There an Effect of Incremental Welfare Benefits on Fertility Behavior?

A Look at the Family Cap

Melissa Schettini Kearney

NBER Working Paper No. 9093

August 2002

JEL No. H53, I18, I38, J13

\begin{abstract}
A number of states have recently instituted family cap policies, under which women who conceive a child while receiving cash assistance are not entitled to additional cash benefits upon the birth of the child. This paper takes advantage of the variation across states in the timing of the policy's implementation to determine if family cap policies are discouraging women from having additional births. Vital statistics birth data for the years 1989 to 1998 offer no evidence that family cap policies lead to a reduction in births to women ages 15 to 34 . The data reject a decline in births of more than one percent. The finding is robust to multiple specification checks. The data also reject large declines in higher-order births among demographic groups with relatively high welfare participation rates. Curiously, the data suggest increases in higher-order births to unmarried black and white high-school dropouts and to unmarried black teens approximately one year after the implementation of a family cap. The data reject a decline in births of more than four percent for unmarried white high-school graduates and unmarried white teens.
\end{abstract}

\author{
Melissa Schettini Kearney \\ Department of Economics \\ Wellesley College \\ Wellesley, MA 02481 \\ and NBER \\ mkearney@wellesley.edu
}




\section{Introduction}

Over the past decade, states across the country have been experimenting with welfare reform. One of the most controversial reform policies, the "family cap" or "child exclusion," is motivated by the notion that an incremental increase in cash assistance for each additional child increases a woman's propensity to bear additional children. With the intention of heightening personal responsibility, 18 states have responded to this concern by implementing family caps that end the traditional practice of providing families on welfare with additional cash benefits when a new child is born into the family. An additional five states have altered the form of the additional benefit, but not eliminated it entirely. This paper uses the variation across states in the timing of family cap implementation to identify whether the denial of incremental benefits leads to a reduction in births.

A woman's decision to give birth is part of a complex series of decisions influenced by social, religious, economic, and other demographic and personal factors. The question of how welfare benefits affect this decision focuses on the role of economic factors in determining this choice. The primary economic question is whether the availability of fewer resources at the margin decreases a woman's propensity to bear additional children. The potential direct effect of the policy is to reduce higher-order births: a decrease in marginal resources raises the price of an additional child and may thereby deter a woman from having additional births. Insofar as the policy sends a message that welfare is less generous than previously, it may also lead a woman to delay childbearing until she is financially secure and thereby reduce first births as well.

The economic theory underlying this question is that of rational choice, and in particular the role of incentives as important determinants of behavior. There is an extensive literature on various potential incentive effects of the welfare system. Econometric studies generally show that labor supply is reduced by the Aid to Families with Dependent Children (AFDC) program and that higher potential benefits induce greater participation in this program. The evidence regarding the effects of AFDC on family structure is more mixed, but recent studies have found a weak effect. ${ }^{1}$

Identifying the causal effects of welfare on fertility decisions is not straightforward. A regression of the number of births a woman has on the welfare benefits she receives confounds the direction of causality. The amount of cash assistance a woman receives is determined by the number of children she has. Many studies have tried to identify the causal relationship by

\footnotetext{
${ }^{1}$ For a survey of the literature see Moffitt $(1998,1992)$.
} 
exploiting cross-sectional variation in state benefit levels and birth rates. The main weakness of this strategy is that there may be fixed differences in birth rates across states that can not be controlled for in a cross-sectional analysis.

This paper addresses these problems by using a plausibly exogenous source of variation in incremental benefits and data from a panel of states. The nineties was a decade of unprecedented welfare reform and experimentation at the state level. The implementation of family caps does not appear to be driven by movements in birth rates. Rather, welfare reform has been a political movement during the time period being studied and state policies have been adopted based on the politics and priorities of the state. For this reason, the legislative "quasi-experiment" is reasonably considered exogenous. Furthermore, the variation in timing across the 18 states that eliminate incremental benefits provides us with multiple quasi-experiments from which we can identify the effect of the policy. The effect of the family cap on fertility behavior is identified using state-level panel data: the analysis compares the change in birth rates for a state that implements a family cap in a given period to the change in birth rates among states that do not implement a family cap in the given period. The analysis controls for level differences in birth rates across states, level differences in birth rates across years that are common to all states, and differences in (linear) birth rate trends among states.

Vital statistics birth data for the years 1989 to 1998 offer no evidence that family cap policies lead to a reduction in births to women ages 15 to 34 . When state effects, month effects, and state-specific linear time trends are controlled for, a decline in births of more than one percent can be rejected at the 95 percent confidence level. (The upper bound of the confidence interval is an increase in births of 1.1 percent.) This finding of no effect on births is maintained across multiple specification checks. The set of confidence intervals around six alternative estimates has a lower bound of a one percent decline and an upper bound of a two percent increase. The data also reject large declines in higher-order births among demographic groups with relatively high welfare participation rates. Curiously, the data suggest increases in higher-order births to unmarried black and white high-school dropouts and to unmarried black teens approximately one year after the implementation of a family cap. The data reject a decline in births of more than four percent for unmarried white high-school graduates and unmarried white teens.

\section{Background}




\section{a. Family cap policies}

In August of 1996 the Personal Responsibility and Work Opportunity Reconciliation Act (PRWORA) replaced the AFDC program with a block grant program called Temporary Assistance for Needy Families (TANF) and gave states flexibility to create new cash assistance programs for families with dependent children, effective July 1997. Before the passage of the PRWORA legislation, many states received waivers from the federal government allowing them to experiment with the rules of welfare. Starting with New Jersey in 1992, nineteen states received approval to implement family cap policies under waivers. An additional four have implemented family cap policies as part of their state TANF programs.

The AFDC program required all states to increase a family's benefit amount when an additional child was born into the family. In contrast, under most family cap policies there is no increase in cash assistance when a child is born to a mother who was receiving welfare at the time of conception. ${ }^{2}$ Some states have implemented partial family cap policies: two states provide only a partial increase in benefits for an additional child; two others provide the increase in assistance in the form of in-kind benefits; and one state gives the incremental increase in cash benefits to a third party (e.g., church) to act on behalf of the child. Appendix Table 1 lists policy types and approval and implementation dates by state.

\section{b. Other recent welfare reforms}

The time period being studied was a time of active welfare reform and experimentation. ${ }^{3}$ Since 1962 the Social Security Act has authorized the Secretary of the Department of Health and Human Services to waive specified requirements of the act in order to enable a state to carry out any experimental, pilot, or demonstration project that the Secretary deems in accordance with the objectives of AFDC. The Reagan, Bush, and Clinton administrations all granted such waivers

\footnotetext{
${ }^{2}$ The following example is taken from Camasso et. al. (1999): in the state of New Jersey, under AFDC, a woman on welfare with one eligible child would receive $\$ 322$ per month in cash assistance. If the woman gave birth to another child, the family would receive an additional $\$ 102$ per month, and an additional \$64 per month for any additional births. Food stamp benefits would also increase, but by less than the maximum due to the incremental income from AFDC benefits. Under the family cap, the family would continue to receive $\$ 322$ with the birth of any additional child. The food stamp benefit would increase by more, however, though not enough to offset the decline in cash assistance.

${ }^{3}$ Information in this section is taken from the 1998 Green Book, Section 7, From the U.S. Government Printing office Online via GPO Access. http://frwebgate.access.gpo.gov/.../105_green_book.
} 
liberally. By mid-August 1996, the Clinton administration had approved more than 70 waivers for more than 40 states.

Many AFDC waiver projects were aimed at encouraging labor force participation and human capital development. Restrictive reforms in this vein include tightened work requirements, time limits on benefit durations, and benefits linked to school attendance or performance.

Liberalizing reforms include a more generous treatment of earnings and resources and an increased vehicle asset limit. Some states received waivers to expand transitional medical and childcare benefits in an effort to encourage recipients to leave the welfare program. Some waivers authorized states to expand eligibility for two-parent (unemployed) families, mitigating the discriminatory affect of AFDC against dual parent families. Many states incorporated provisions of their AFDC waiver projects into their TANF plans. Appendix Table 2 lists approval and implementation dates of states' first major waivers.

To empirically identify the effect of family cap policies on birth rates, it is necessary to control for the effect that other welfare initiatives might have had on fertility decisions. Tightened work requirements in the form of less generous child exemptions are such a policy. Under AFDC, primary caretaker relatives of children up to six years of age, or up to three if the state guaranteed childcare, were exempt from the requirement that adults participate in the Job Opportunities and Basic Skills Training (JOBS) program. Thirteen states received waivers to alter their JOBS requirements, most commonly to lower the age of the youngest child that qualifies a recipient for a work exemption and in some cases to eliminate the caretaker exemption. All states imposed tightened work requirements under TANF requiring welfare recipients to work sooner in terms of the age of their youngest child. The implementation of stricter requirements may affect fertility behavior, since the cost to a woman of having a child is higher when the child does not qualify her for a work exemption or does so for a shorter amount of time. The econometric analysis below therefore controls for changes in work exemption rules. Appendix Table 3 lists work exemption policies and implementation dates by state.

If women perceive children to be a hindrance to financial self-sufficiency, time limits on benefits may affect reproductive decisions by signaling that welfare assistance is only temporary. ${ }^{4}$ AFDC imposed no restrictions on the length of time a family could receive welfare assistance. Twenty-four states received waivers to implement benefit time limits and under PRWORA, all

\footnotetext{
${ }^{4}$ A time limit refers to a length of time for which a family can receive cash assistance and after which a family's benefit is either terminated or reduced or the family is required to participate in work requirements
} 
states are required to impose benefit time limits. PRWORA also mandates that state TANF plans subject teen parents to stay-in-school and live-at-home provisions. In order to isolate the effect of a family cap policy from any effect these restrictive provisions might have had on birth rates, the econometric estimation controls for the implementation of time limits and state TANF plans. Appendix Table 2 lists time limit and TANF implementation dates.

\section{c. Previous studies on the effect of welfare on fertility}

There is a large body of research from the past three decades on the effects of the welfare system on family structure. Studies from the 1970s and early 1980s generally fail to demonstrate an effect of welfare on marriage and fertility outcomes. Moffitt (1992) provides an overview of this early research. A second-wave of studies dating back to the mid-1980s offers mixed findings but has led to a tenuous consensus that the welfare system probably does affect marriage and fertility outcomes. However, as Moffitt (1998) observes, "there is considerable uncertainty surrounding this consensus because a significant minority of the studies finds no effect at all, because the magnitudes of the estimated effects vary widely, and because there are puzzling and unexplained differences across the studies by race and methodological approach."

Many studies utilize cross-state comparisons of benefit levels to estimate the effect of welfare on fertility. Using data from the National Longitudinal Survey of Youth (NLSY), Lundberg and Plotnick $(1990,1995)$ find strong effects on pregnancy probabilities and resolution decisions for white teenage women but not for blacks. On the other hand, Acs $(1994,1996)$ analyzes data from the NLSY and finds no effect of welfare for either whites or blacks on the probability that a woman age 23 to 25 has a second birth nor on the probability that a woman age 14 to 23 has a first birth. Duncan and Hoffman (1990) and An, Haveman, and Wolfe (1993) also rely on cross-state comparisons of benefit levels but these studies use data from the Panel Study on Income Dynamics (PSID). The former analyze the fertility decisions of black teens and do not find a significant effect of welfare on AFDC-related births. The latter do not find a significant effect on the probability that a woman age 13 to 18 has a non-marital birth.

A weakness of these studies, as well as other studies relying on cross-state comparisons, is that the results are potentially biased by unobserved differences across states. Benefit levels and

fertility decisions may covary across states for reasons other than a direct welfare effect. In an analysis of PSID data from 1969 to 1989 , Hoynes (1997) confirms that results are sensitive to the 
inclusion of state fixed effects and explores the possibility that population composition varies across states in ways related to welfare program generosity. Her results show that when the estimation procedure controls for individual effects, there is no evidence that welfare raises the propensity to form female-headed households for either whites or blacks. Similarly, Moffitt (1994), using Current Population Survey (CPS) data from 1968 to 1989 and a cross-state comparison of levels, finds positive welfare effects for whites on the probability that a woman with less than 12 years of education is a household head. But when he controls for state fixed effects in the estimation, he finds a negative effect. In contrast, Rosenzweig's (1999) analysis of NLSY data controls for state and cohort fixed effects and finds a significant and quantitatively large positive effect of AFDC on nonmarital childbearing through age 22. Hoffman and Foster (2000) demonstrate the sensitivity of estimates to the age group examined. They reproduce Rosenzweig's main findings using data from the PSID, but when they examine fertility separately by age, they find an AFDC effect only for women in their early twenties and not for teenage women.

Some recent work focuses on the effect of marginal welfare benefits. Argys and Rees (1996) examine the relationship between welfare generosity and fertility behavior using data on an NLSY sample of 1,344 unmarried women who received welfare payments at some point between 1979 and 1991. Controlling for state fixed effects, they find neither the welfare guarantee level nor the marginal benefit level to be a significant determinant of conception probability. Robins and Fronstin (1996) estimate the effects of changes in benefit increments on family-size decisions among a CPS sample of never-married women. Their analysis finds that both the benefit level and the incremental benefit for a second child positively affect family size decisions of black and Hispanic women, but not of white woman. Fairlie and London (1997) estimate the probability of a higher-order birth for a sample of AFDC recipients and a comparison sample of non-AFDC women using data from the Survey of Income and Program Participation (SIPP). They find a stronger effect for the non-AFDC sample than for the AFDC sample and therefore conclude that the observed relationship is spurious.

The literature has demonstrated that the estimation of a fertility effect of welfare is sensitive to the data set being analyzed, the age of the population being studied, and the methodology employed. The majority of studies have relied on cross-state comparisons, which are potentially unable to identify a causal link between welfare and fertility. The present study improves upon previous studies in a number of ways. To identify an effect of incremental welfare benefits on fertility decisions, the analysis relies on an arguably exogenous source of change in incremental benefit levels induced by the political welfare reform movement. The changes in benefits 
implemented under family cap policies occur at different times across states, so the estimation can control for the effects of time. In addition, the analysis uses state-level panel data so the estimation can control for state fixed effects. Furthermore, the present study uses vital statistics data on all births to all women and can therefore directly observe whether results extend across race and age groups.

\section{d. Studies of family cap policies}

Two states, Arkansas and New Jersey, have released evaluations of their family cap policies. Both evaluations employ an experimental design: women receiving welfare were randomly assigned to a treatment group that was subject to a benefits cap, and a control group that was not. The Turturro et al. (1997) evaluation of the Arkansas program for years 1994 to 1997 finds no statistical difference in the number of births born to women in the two groups. Camasso et al. (1999) use two analytical approaches to evaluate New Jersey's experience: an experimental design as described above and a pre-post analysis of the entire welfare caseload over a 6-year period that includes the implementation of the family cap. Both analyses suggest that pregnancies and births among women on welfare declined after program implementation and that the number of abortions increased.

Studies of targeted experiments such as these are always open to questions about whether the results apply to other contexts. In addition to this general problem, methodological weaknesses inherent in the Arkansas and New Jersey studies make the results of these studies difficult to interpret. First, there is evidence that the experimental design was contaminated in both demonstrations. Loury (2000) reports that in both demonstrations many members of the treatment and control groups did not know which policy applied to them. ${ }^{5}$ Furthermore, in New Jersey, more than one-quarter of case workers admitted to evaluators that they used discretion when making treatment or control assignments, thereby negating the randomness of the assignment. Loury also points out that the surveys on which the evaluations were based had low response rates and that the respondents were not representative of the larger AFDC caseload.

In addition to implementation problems, the Arkansas and New Jersey evaluations both restrict the analysis to women on welfare, which makes it impossible to identify the effect of the

\footnotetext{
${ }^{5}$ In Arkansas, 46 percent of women in the treatment group and 52 percent in the control group indicated to evaluators that they did not know how much more money that would receive if they had an additional child. In New Jersey, only 39 percent of the actual control group members knew they were in the control group and only 65 percent of treatment group members knew that they were subject to new rules (Loury 2000).
} 
family cap on fertility behavior separately from the effect on welfare participation. The existence of a family cap may lead to compositional changes among the welfare population that preclude the analysis from estimating a causal effect on births. On the one hand, a family cap policy may encourage women who desire multiple children to find alternative means of financial support, e.g. a paying job or a husband. To the extent that this occurs, the welfare population post-family cap includes fewer women who desire multiple children. Ceteris paribus, birth rates are unchanged, but there are fewer births to women on welfare. On the other hand, the presence of a family cap may signal that welfare is not a generous source of financial support, leading some young women to delay becoming a mother until they are more financially secure. Some women who might have given birth and enrolled in welfare pre-family cap do neither when a family cap policy is in effect. Ceteris paribus, birth rates are lower as a consequence of the family cap but there is no change in the number of births to women on welfare. Due to these concerns, the empirical analysis below is not conditioned on welfare receipt and avoids confounding the effect of the family cap on birth rates with the effect on participation. ${ }^{6}$

In a contemporaneous working paper, Horvath-Rose and Peters (2000) examine aggregate vital statistics birth data from 1984 to 1996 to analyze the effect family cap policies have had on state-level non-marital birth ratios. ${ }^{7}$ Their study concludes that the family cap decreases non-marital fertility for all race and age groups. The main regressions of their study control for state and year fixed effects, high-school completion rate by adults age 18 to 24, proportion of state population living in urban areas, proportion of state population that are fundamentalist adherents, and indicator variables for the following welfare policies: minor parent provision waiver, time limit waiver, work requirement waiver, AFDC-UP waiver, child support waiver, expanded income disregard and asset limit waiver, school attendance and performance requirement waiver, parental consent requirement for an abortion, requirement for sex education in schools.

There are three major limitations to the Horvath-Rose and Peters (2000) framework. First, by defining the dependent variable in terms of the non-marital birth ratio, the analysis confounds the marriage and fertility responses to the family cap. Furthermore, though marital status is key to their study, the authors do not account for the changes in the reporting of marital status in vital statistics

\footnotetext{
${ }^{6}$ Declines in welfare caseloads over the 1990s are well-documented (see Ziliak et al. 2000). Whether welfare reform or the robust economy are responsible for the declines, if the composition of the welfare caseload has been altered then conditioning the analysis sample on welfare-receipt is problematic.

${ }^{7}$ The non-marital birth ratio is defined as the number of non-marital births divided by the total number of births.
} 
data that occurred during the time period they study. ${ }^{8}$ Second, there are potential problems with their waiver variables, which differ substantially from those in the 1999 CEA report and 1998 Urban Institute report. Third, the results appear to be implausible. For women ages 20 to 49, the analysis finds an immediate decrease of 1.4 percentage points off a base of 21 percent for white women and an immediate decrease of 3.1 percentage points off a base of 51 percent for black women. For teenage women, their analysis finds immediate decreases of 4.5 percentage points off a base of 58 percent among whites and 3.2 percentage points off a base of 87 percent among blacks. These results imply an immediate marriage response, third trimester abortions, or large anticipation effects. Additionally, it is curious that such a large effect is observed for the entire population of women aged 20 to 49, most of whom will never be at-risk of welfare receipt.

\section{Data and Empirical Strategy}

\section{a. Data}

Data on births are from the 1989 to 1998 Vital Statistics Natality Data, Public-Use Data Files compiled by the U.S. National Center for Health Statistics (NCHS). The public-use data files include all births occurring within the United States. I limit my sample to births occurring to women ages 15 to 34 because women in this age group are more likely to be at-risk of welfare dependence - and hence affected by a family cap policy - than older women. The vital statistics data files identify the state of residence and month of birth, as well as mother's education, mother's race, mother's marital status, and live-birth order. I use this information to create a data file of state birth counts.

Information on welfare policies is obtained from three sources. The first source is a 1999 technical report of the Council of Economic Advisors (CEA), which relied on experts from the Department of Health and Human Services as well as non-governmental research institutions. The second source is a 1998 Urban Institute report on state TANF programs. The third is a report by Crouse (1999), prepared for the U.S. Department of Health and Human Services, which summarizes

\footnotetext{
${ }^{8}$ As reported in the technical appendix of the 1997 vital statistics report, birth certificates in 46 states and Washington D.C. include a direct marital status question. Nevada collects marital status information from the electronic birth registration process, though it is not included on the birth certificate. This procedure was started in Nevada in 1997 , after 1995-1996 procedures overestimated the number of births to unmarried women. The remaining three states of Connecticut, Michigan, and New York make marital status determinations based on whether a paternity acknowledgement was received, the father's name is missing, and lastly, whether the father's and mother's surnames are different. A direct question was not added in Texas and California until 1994 and 1997, respectively.
} 
information contained in a 1997 report of the U.S. Department of Health and Human Services Setting the Baseline: A Report on State Welfare Waivers.

\section{b. Empirical Strategy}

The effect of the family cap on fertility can occur through two channels: conception and abortion. Economic reasoning predicts that the existence of a cap on benefits for additional children raises the price of a child and might therefore lead some women to avoid pregnancy or, once becoming pregnant, avoid a birth by having an abortion. This reasoning finds a foundation in Becker's models of the family. Becker (1981) uses the price of children and the real income to explain, among other things, why a rise in the wage rate of employed women reduces fertility and why various government programs - such as AFDC - might significantly affect the demand for children. Assuming that women, on average, respond to a price increase of an additional child, we expect that the number of higher-order births in a state that has effectively raised the price of additional children will fall relative to a state that has not, all else being constant.

The analysis of this paper identifies the sum of the conception and abortion responses and reports the net effect of the family cap on reproductive behavior. It is estimated at the aggregate level, looking at the number of births in a state-month cell. The identification strategy of this paper is to compare the change in the number of births occurring in a state that becomes a family cap state to the change in the number of births that occurs in states that do not make the family cap transition in the same period. Relative to states that have not yet passed a family cap, or that did so in the past, this analysis identifies the incremental change in births that is associated with the introduction of the family cap.

The estimation technique applies ordinary least squares (OLS) regression to model fertility in state $s$ in month $t$. The base estimating equation, eq. (1), takes the following form:

$$
\begin{aligned}
& \ln (\mathrm{y})_{\mathrm{st}}=\alpha+\beta_{1} * \text { famcap }_{\mathrm{st}}+\beta_{2} * w k e 1_{\mathrm{st}}+\beta_{3} * w k e 2_{\mathrm{st}}+\beta_{4} * w k e 3_{\mathrm{st}}+\beta_{5} * \ln (\text { welfare } \\
& {\text { benefits })_{\mathrm{sy}}+\beta_{6} * T A N F_{\mathrm{st}}+\beta_{7} * \text { time limit }}_{\mathrm{st}}+\beta_{8} * \ln (\text { female pop } 15-34)_{\mathrm{sy}}+\beta_{9} *(\text { prop 15- } \\
& \text { 19) })_{\mathrm{sy}}+\beta_{10} *\left(\operatorname{prop}_{20-24)_{\mathrm{sy}}}+\beta_{11} *\left(\text { prop } 25-29_{\mathrm{sy}}+\beta_{12} * \text { unemp rate }_{\mathrm{s}(\mathrm{t}-9)}+\gamma_{\mathrm{s}}+\right.\right. \\
& \sigma_{\mathrm{t}}+\xi_{\mathrm{s}} * \text { time }+\varepsilon_{\mathrm{st}}
\end{aligned}
$$

The variables are defined as follows:

$\mathrm{y}_{\mathrm{st}} \quad-$ total number of births in state $s$ in month $t$ to women age 15 to 34 
famcap $_{s t}$ - a binary indicator for whether state $s$ implemented a family cap at least six-months prior to month $t$ $w k e 1_{\mathrm{st}}$ - work exemption 1 - a binary indicator for whether state $s$ implemented an exemption for mothers with a child as old as six months to three years $w k e 2_{\text {st }}$ - work exemption 2 - a binary indicator for whether state $s$ implemented an exemption for mothers with a child newly born to six months old $w k e 3_{\text {st }}-$ work exemption 3 - a binary indicator for whether state $s$ removed exemptions based on the age of a mother's child welfare benefits $s_{s y}$ - the maximum monthly benefit for a family of three on AFDC/TANF in state $s$ in year $y$, expressed in 1998 dollars $^{9}$

$T A N F_{s t}-$ a binary indicator for whether a state implemented its TANF plan at least six-months previous to month $t$

time limit $_{s t}$ - a binary indicator for whether a state implemented a time limit on welfare benefits at least six-months previous to month $t$

female pop 15-34sy - the female population age 15 to 34 , in state $s$ in year $y$, based on U.S. census figures

prop15-19 ${ }_{s y}$, prop20-24 sy, prop25-29 ${ }_{s y}$ - the proportion of the female population age 15 to 34 in the different five-year age groups, in state $s$ in year $y$; omitted category is the proportion age 30 to 34 .

unemp rate $_{\mathrm{s}(\mathrm{t}-9)}$ - the average unemployment rate in state $s$ in the six months around the month of conception, $t-9$

$\gamma_{\mathrm{s}}-$ a binary indicator for state $s$

$\sigma_{\mathrm{t}} \quad-$ month fixed effects for month $t$

$\xi_{\mathrm{s}} *$ time - linear time trend specific to state $s$

The analysis sample consists of 6,120 observations (51 states over 120 months). The dependent variable is the natural logarithm of the total number of births in state $s$ in month $t$ to women age 15 to 34 . In subsequent specifications, the model is estimated for higher-order births to women in more narrowly defined demographic groups. The distribution of total monthly births in a state is highly skewed, so a log transformation of the birth count is used. An advantage of this transformation is that coefficients reflect percentage changes, which aids in the interpretation of 
results. A potential problem with defining the dependent variable at the state-level is that the analysis will provide unbiased estimates of the effect of the family cap on birth rates only if there is not widespread migration in response to family cap policies. This assumption finds support in Levine and Zimmerman (1999), which evaluates the extent to which differences in welfare generosity across states leads to interstate migration and concludes that welfare-induced migration is not a widespread phenomenon.

The variable of primary interest is the binary indicator for a family cap. I refer to the 18 states that between 1989 and 1998 eliminate additional cash assistance for a child born to a mother on welfare as "ever-treated" states and to the other 32 states and the District of Columbia as "nevertreated" states. For the never-treated states, the family cap indicator is always equal to zero. For the ever-treated states, the family cap indicator takes on a value of one if the observation represents a month that occurs at least six months after the state's family cap policy was implemented. Allowing a six-month lag recognizes that conception responses can not take place within nine months of the policy implementation and that most abortion responses will occur in the first trimester of pregnancy. An alternative specification defines the family cap to incorporate a 12-month lag, which assumes that there is no immediate abortion response.

The three work exemption variables are included in the model to control for the effect that tightened work restrictions might have on fertility decisions. They are mutually exclusive and the omitted category is the traditional AFDC/JOBS exemption policy. As discussed above, the relative cost of having a child is higher when the child does not exempt the mother from work requirements. Economic reasoning thus implies the sign of $\beta_{2}, \beta_{3}$, and $\beta_{4}$ to be non-positive, and since wke1 represents the least strict non-AFDC policy and wke3 represents the strictest, we expect that $\beta_{4}<=\beta_{3}<=\beta_{2}$. The welfare benefit level is controlled for in the model to account for any change in benefit levels that may be correlated with the introduction of a family cap policy and affect fertility decisions. Eleven states explicitly changed their benefit levels under TANF and the inflationadjusted level of benefits declined in almost all states during the nineties. All else equal, a higher benefit level makes raising a family on welfare less-costly, and economic reasoning thus predicts that the sign on $\beta_{5}$ is positive.

The model also controls for the implementation of time limits and state TANF plans. As discussed above, a time limit on benefit durations may affect reproductive decisions insofar as it signals that assistance is temporary and encourages women to delay childbearing until they are

\footnotetext{
${ }^{9}$ I thank Robert Shoeni for providing me with this data, which was used in the 1999 CEA report.
} 
financially secure. TANF plans may affect fertility behavior through mechanisms other than a family cap; all state TANF plans subject teen parents to stay-in-school and live-at-home provisions. The advantage of including these control variables in the model is that the estimated effect of the family cap will not include any effect these restrictive provisions may have on birth rates. A potential disadvantage is that the data may not have enough statistical power to separately identify partial effects for highly correlated welfare reform variables, especially in empirical specifications that limit the sample to narrowly defined demographic groups. Robustness checks are performed to determine whether the estimated effect of the family cap is sensitive to the inclusion of these controls.

The regression model explicitly controls for the natural logarithm of the female population age 15 to 34 . If the female population is trending non-linearly, then the state-specific linear time trend will not adequately capture population movements, which undoubtedly affect birth counts. The proportion of women in each five-year age group is also controlled for, to account for idiosyncratic demographic shifts that might be spuriously correlated with the implementation of family cap policies. Data on population are obtained from the U.S. census bureau. The model also explicitly controls for the average state unemployment rate in the three months before and three months after conception. This variable is included to capture shifts in economic conditions that are not uniform across states nor are adequately described by a linear state trend. Individual state fixed effects are accounted for in the regression to control for level differences in birth rates across states. (Ever-treated states have higher birth totals than never-treated states on average.) Indicator variables for the particular month are included to account for any idiosyncratic movements in birth rates common to all states.

The identification strategy relies on the assumption that birth rates in states that implement family caps are not trending differently than birth rates in other states pre-family cap. This assumption is tantamount to assuming that the introduction of family cap legislation is exogenous to birth rate trends. Two empirical tests support this assumption. First, Figure 1 plots annual fertility rates, defined as births per 1,000 women in the relevant age group. The data reveal no sign of divergent trends prior to the mid-1990s for either women age 15 to 19 or women age 20 to 34 . Second, as discussed below, the data suggest that the approval of a family cap waiver is not positively associated with births, which would be the case if an increase in birth rates led a state to request a waiver to implement a family cap. Nonetheless, one would prefer not to have to rely on this assumption. To relax it to some degree, the model is estimated with controls for state-specific 
time trends, denoted in months. These controls allow fertility rates to trend uniquely, albeit linearly, for each state without undermining the viability of this empirical strategy.

\section{Results and Conclusion}

\section{a. Differences in fertility rates, by treatment status and demographic group}

Table 1 lists mean total monthly births and fertility rates for the overall sample of states. It also lists birth counts separately for never-treated states pre- and post-1996 and for ever-treated states pre- and post- family cap implementation (with a six-month lag). ${ }^{10}$ The first row of the table reports that for women age 15 to 24 , the average monthly fertility rate - defined as births per 1,000 women - declines from an average of 7.6 to 7.4 in ever-treated states and from 7.6 to 7.3 in nevertreated states. There was no change in the average monthly fertility rate among women age 20 to 34 in either group of states. The fall in the fertility rate of teens was slightly greater in never-treated states. Under the assumption that fertility rates would have trended similarly in the two groups of states in the absence of the policy intervention, these unadjusted "difference-in-differences" imply that the family cap did not noticeably affect fertility rates of women age 15 to 34 . Figure 1 makes the point visually that at no point between 1989 and 1998 does average monthly fertility decline more sharply (or increase less steeply) for states that implement caps relative to states that do not.

One problem with looking at the fertility rates of all women age 15 to 34 is that many women will never be at-risk of welfare dependence and therefore will not respond to welfare reform initiatives such as the family cap. To narrow the analysis, twelve demographic groups are identified based on race ${ }^{11}$, marital status, and education. Women age 20 to 34 are divided into high-school graduates and high-school dropouts; women age 15 to 19 are classified simply as teens in order to avoid mislabeling young women still in school as dropouts. According to data from the March 1989 Current Population Survey (CPS), unmarried high-school dropouts have the highest welfare participation rate -61.9 percent among black women and 36.9 percent among white women. The rate among unmarried high-school graduates is 22.0 percent among blacks and 5.5 percent among whites.

\footnotetext{
${ }^{10}$ The year 1996 is chosen as the breakpoint for never-treated states because only one state implements a family cap after 1996.

${ }^{11}$ For ease of exposition, women whose race is not classified as "black" in the natality files are considered "white".
} 
Unadjusted difference-in-difference calculations suggest that relative to states that did not, states that implemented family caps experienced a greater decline in the number of births born per month to white unmarried high-school dropouts, but not in the number of births born to black unmarried high-school dropouts. The same is true for births born to unmarried high-school graduates. However, states that implemented family caps also experienced larger relative declines in the total number of births born to married white women. As the proportion of married women who receive welfare is extremely low (5.3 percent among high-school dropouts and 1.2 percent among graduates), this suggests that something other than the family cap is driving these trends. Indeed, the regression-adjusted estimates for these groups show no relative decline, as discussed below.

Population estimates are not available for these narrowly defined demographic groups so it is not easily determined whether differential demographic shifts are behind these trends. To be clear, the birth totals listed for the twelve demographic groups in Table 1 do not account for demographic shifts in the composition of the female population. The top panel of Table 1 shows that mean monthly birth totals fall more in ever-treated states even though fertility rates do not. This discrepancy suggests that population demographics shifted differently between the two groups of states. This highlights the importance of accounting for state-specific time trends and population demographics in the regression analysis.

\section{b. Regression results - all births to women 15 to 34}

Table 2 displays the results from estimating equation (1) and six specification checks for the full sample of women age 15 to 34 . In the base specification the dependent variable is the natural logarithm of the total number of births in state $s$ in month $t$. The family cap indictor equals one if the state of observation eliminated benefits for an additional child six or more months previous to the month of observation. The base specification controls for state effects, month effects, statespecific linear time trends, population demographics, lagged state unemployment, and the full set of welfare reform variables. The table reports robust standard errors that incorporate White's correction for an arbitrary covariance structure between observations within a state and year (see Bertrand et al. 2001) $)^{12}$.

The estimation of equation (1) yields a point estimate of the effect of a family cap of 0.002 , with a standard error of 0.005 . The $95 \%$ confidence interval around this estimate ranges from a

\footnotetext{
${ }^{12}$ This is implemented using the "cluster" command in STATA.
} 
negative effect of 0.8 percent to a positive effect of 1.1 percent. The data reject the hypothesis that a family cap leads to a decline in births of one percent or more. Benefit levels have a statistically significant positive effect on birth rates and unemployment has a statistically significant negative effect. Controls for the implementation of tightened work exemptions, a time limit on benefits, and a state TANF plan enter the model insignificantly. This finding of no effect is maintained across the six alternative specifications. The set of confidence intervals around the six alternative estimates has a lower bound of -0.01 and an upper bound of .02 .

The specification presented in column 2 removes the time limit and TANF variables from the model. The motivation for this specification is that it may be difficult for the data to parse out the effects of highly correlated welfare reform variables, and perhaps this is why estimation of equation (1) fails to detect a negative effect of the family cap. The results do not support this explanation; the estimated coefficient on the family cap indicator is unchanged. Column 3 displays the estimated coefficients when the model does not account for differential time trends across states. Perhaps the time trend variables in the base specification are capturing the variation in birth rates that would otherwise identify a family cap effect. The results do not support this explanation either. The point estimate of $\beta_{1}$ remains 0.002 .

In the specification listed in column 4, the family cap indicator incorporates a twelve-month lag. The base case of a six-month lag allows an initial abortion response from women in their first trimester of pregnancy; a twelve-month lag assumes more time is needed for a response. The estimated coefficient is positive and significant: 0.009 with a standard error of .004 . This is a surprising result, as there is no reason to suspect that the elimination of benefits for an additional child leads to an increase in births. The result will be explored in more detail below.

The specification in column 5 investigates the effect of the approval of a family cap policy, rather than the implementation. The estimated coefficient is 0.002 , the same as in columns 1,2 , and 3. This finding affirms the assumption that family cap policies are not adopted in response to positive shifts in birth rates. A more skeptical interpretation is that the adoption of a family cap is positively correlated with births, but that it is offset by an "anticipation" effect whereby women avoid pregnancy when they learn that a family cap will soon be imposed. Because there appears to be no decline in births after the family cap is implemented, this interpretation seems highly unlikely. ${ }^{13}$

\footnotetext{
${ }^{13}$ Another way to potentially address endogeneity is to distinguish between states that adopted the family cap as part of TANF and those that requested family cap waivers. States that request waivers are arguably more likely to be
} 
The two final specification checks reported alter the form of the dependent variable. The regression reported in column 6 estimates the equation for the natural logarithm of the fertility rate. The mean fertility rate across the 6,120 state-month cells in the sample is 7.6 births per 1,000 women. Defining the dependent variable this way essentially moves the natural logarithm of the female population age 15 to 34 from the right-hand side of the equation to the left- hand side, i.e. it restricts the coefficient on the population variable to be one. In this specification, the estimated effect lies between a decrease of 0.6 percent in the fertility rate and a 1.1 percent increase. Again, the data suggest that if the effect of the family cap is negative, it is smaller in absolute terms than one percent.

The final specification defines the dependent variable as the natural logarithm of the nonmarital birth ratio - defined as the number of births to unmarried women divided by the total number of births - as do Horvath-Rose and Peters (2000). The estimated coefficient on the family cap indicator is -0.0003 with a standard error of 0.006. In contrast, Horvath-Rose and Peters (2000) find a statistically significant lagged decline in the non-marital ratio of women age 20 to 49: they estimate a decline of eleven percent for white women and approximately eight percent for black women. The data in the present analysis reject a negative effect larger than 1.2 percent for all women age 15 to 34 at the 95 percent confidence level.

\section{c. Regression results - higher-order births, by demographic group}

The above analysis fails to detect a decline in births associated with the implementation of a family cap. But perhaps additional births to women at-risk of welfare dependence comprise only a small fraction of births born to women ages 15 to 34, making it statistically difficult for the analysis to detect an effect. In order to target the analysis to fertility decisions that are potentially affected by welfare reform, I limit the analysis on higher-order births. ${ }^{14}$ In addition, equation (1) is estimated separately for the twelve demographic groups defined above to so that we can compare estimated effects across populations with different welfare participation rates. The trade-off inherent to this

responding to shifts in birth outcomes than are those states that implement a cap as part of the national reform of welfare. However, 19 out of the 23 states that enact any type of family cap legislation requested waivers to do so, making the exercise meaningless. Instead, I re-estimate equation (1) after dropping the set of five states that had waivers approved before 1995 when a family cap was still a novel idea. The point estimate in this specification is -0.002 , with a standard error of .009.

${ }^{14}$ Point estimates for the effect of the family cap on first births are not significantly different from zero; results are listed in Schettini (2000). 
approach is that while the power of the analysis is strengthened by the focus on a more targeted sample, it is weakened by a decrease in sample size.

Table 3a reports the results for the eight demographic groups age 20 to 34 and Table $3 \mathrm{~b}$ reports results for the four groups of teenage women. The estimated effect of the family cap is not statistically different from zero for any of the groups, but the standard errors are roughly five times as large as the standard errors for the full sample estimates. Estimating equation (1) for higher-order births born to black, unmarried high-school dropouts yields a coefficient of 0.057 on the family cap indicator, with a standard error of 0.025 . With a welfare participation rate of 62 percent, this is the group most likely to be affected by welfare reform. The estimated coefficient on the family cap indicator for white, unmarried high-school dropouts - the group with the second highest rate of welfare participation - is also curiously positive and statistically significant. ${ }^{15}$ It is investigated further in Table 4.

A sizeable percentage of black, unmarried high-school graduates receive welfare -22 percent, according to the 1989 March CPS. But the data provide no evidence that a family cap leads to a decrease in higher-order births among this group either. The estimated coefficient is 0.010 ; the 95 percent confidence interval for additional births extends from a decline of 2.7 percent to an increase of 4.7 percent. Black, married high-school dropouts also report a relatively high rate of welfare participation, 12.9 percent. But women in this group also appear to be unresponsive to the family cap. The data yield a point estimate of 0.042 , with a 95 percent confidence interval ranging from -0.033 to 0.118 .

The other demographic groups listed in Table 3 a have low rates of welfare participation and not surprisingly, do not appear to respond to the implementation of a family cap. As shown in Table $3 b$, the data do not suggest a family cap effect among teenage women either. The estimated coefficient on the family cap indicator is -0.012 for higher-order births to unmarried white teens, with a standard error of 0.014 . The data reject a decline of more than four percent at the 95 percent confidence level. The estimated coefficient is 0.069 for unmarried black women and is curiously statistically significant.

A potential objection to looking separately at births to unmarried and married women is that marriage decisions may be affected by the introduction of a family cap. Some pregnant unmarried women may respond to a family cap by getting married. If this were the case, the data would 
indicate a decrease in births to unmarried women and a corresponding increase in births to married women. However, the results in Tables $3 \mathrm{a}$ and $3 \mathrm{~b}$ do not suggest that the introduction of a family cap is associated with an increase in the number of higher-order births born to married women.

Table 4 explores the positive coefficient on the family cap indicator found among three samples of women: black unmarried high-school dropouts, white unmarried high-school dropouts, and black unmarried teens. For the sake of completeness, the table also reports results for white unmarried teens. The family cap indicator is replaced with a set of seven indicator variables that control for three-month intervals before and after the implementation of the family cap: three to six months before, zero to two months before, one to three months after, four to six months after, seven to nine months after, ten to twelve months after, and more than a year after. If the positive coefficient is picking up a spurious correlation between birth rates and the introduction of a family cap policy, this might be evidence that the policy "exogenous" to birth rates. The results of this exercise suggest that this is not the case. For unmarried high-school dropouts, the positive association does not appear until more than a year after the family cap has been implemented. For unmarried black teenagers the positive association does not appear until several months after the policy. There is some spurious positive association that is not explained by population shifts nor unemployment rates. When additional years of data become available, future research should explore this curious finding.

To explore this positive estimate further, I estimate equation (1) for higher-order births to high-school dropouts with the dependent variable specified as the natural logarithm of the nonmarital birth ratio, rather than the natural logarithm of the total number of births. The estimated effect on the non-marital birth ratio of high-school dropouts is not significantly different from zero for either white or black women. The estimated coefficient on the family cap indicator is -0.015 for blacks, with a standard error of 0.013 , and 0.012 for whites, with a standard error of 0.013 . This implies that there was not an upward shift in births to unmarried women relative to married women, which provides some assurance that there is not some confounding factor affecting the fertility decisions of women with high rates of welfare participation.

\section{d. Discussion and policy implications}

\footnotetext{
15 This finding stands in stark contrast to the finding of Camasso et al. (1999) in the case of New Jersey's family cap. Their study reports that births declined by nine percent among longer-term welfare recipients and by twelve percent
} 
This paper has found no systematic effect of the family cap on fertility rates. The data reject a decline in births of more than one percent to women age 15 to 34 . The data detect no significant decline in higher-order births among demographic groups with relatively high welfare participation rates. If this empirical result is correct, then the widespread adoption of the family cap as a state welfare policy appears ineffective at best and misguided at worst. Women are not responding by having fewer additional births, and consequently, fewer resources are being provided per child on welfare.

Future research could help determine whether these results are conclusive. The data suggest that for some demographic groups there is a positive shift in births several months after a family cap policy is implemented. The present analysis is unable to account for this curious result. In addition, the analysis incorporates limited post-family cap data. Most states that eliminated cash assistance for additional children did so in 1995 and 1996 and vital statistics birth data is only available through 1998. It is possible that effects on fertility will not be evident for another couple years. When additional years of natality data become available, future research should examine the positive association and investigate whether the finding of no response holds in the long run. 
Figure 1: Monthly Fertility Rates

All women age 15 to 34

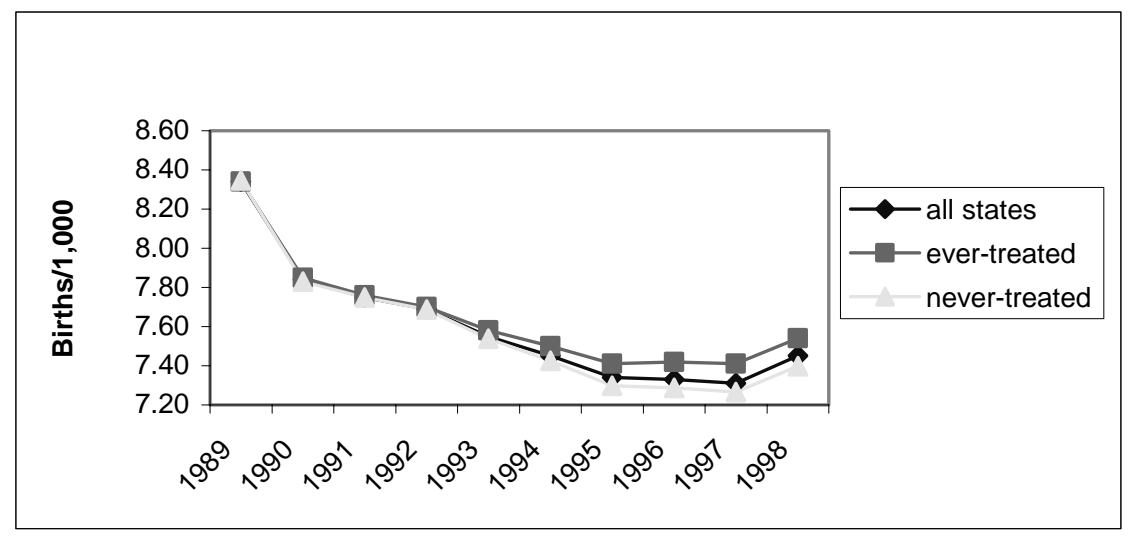

All women age 20 to 34

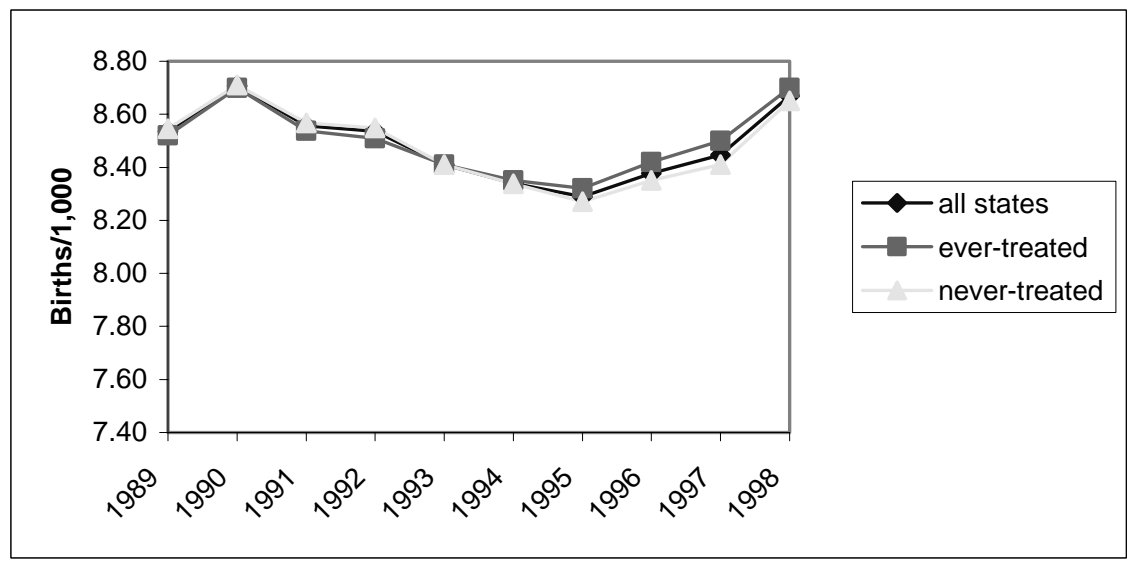

All women age 15 to 19

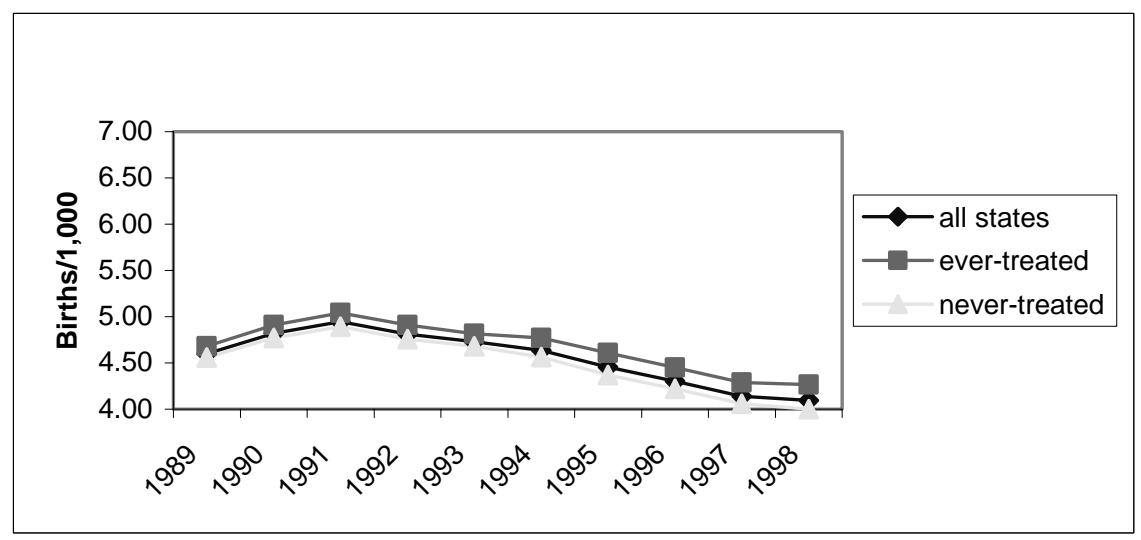




\begin{tabular}{|c|c|c|c|c|c|c|}
\hline \multicolumn{7}{|c|}{$\begin{array}{c}\text { Table } 1 \\
\text { Mean Monthly Birth Totals } \\
1989 \text { to } 1998\end{array}$} \\
\hline & \multirow[t]{2}{*}{ Overall } & \multicolumn{2}{|c|}{ Never-treated } & \multicolumn{2}{|c|}{ Ever-treated } & \multirow{2}{*}{$\begin{array}{l}\text { Diff-in- } \\
\text { diff } \\
\text { (d-c)-(b-a) }\end{array}$} \\
\hline & & $\begin{array}{c}1989-95 \\
\text { (a) }\end{array}$ & $\begin{array}{c}1996-98 \\
\text { (b) }\end{array}$ & $\begin{array}{c}\text { pre- } \\
\text { famcap } \\
\text { (c) }\end{array}$ & $\begin{array}{l}\text { post- } \\
\text { famcap } \\
\text { (d) }\end{array}$ & \\
\hline all women age 15-34 & 5,809 & 5,221 & 4,933 & 7,362 & 6,152 & -922 \\
\hline per 1,000 women & 7.6 & 7.6 & 7.3 & 7.6 & 7.4 & 0 \\
\hline all women age 20-34 & 4,988 & 4,486 & 4,222 & 6,328 & 5,288 & -776 \\
\hline per 1,000 women & 8.5 & 8.5 & 8.5 & 8.5 & 8.5 & 0 \\
\hline all female teens $15-19$ & 820 & 735 & 711 & 1,034 & 863 & -147 \\
\hline per 1,000 women & 5.0 & 4.7 & 4.1 & 4.8 & 4.4 & 0 \\
\hline \multicolumn{7}{|c|}{ unmarried HS dropouts age 20-34 } \\
\hline (1) black & 130 & 127 & 105 & 153 & 136 & 5 \\
\hline white & 283 & 196 & 228 & 472 & 291 & -213 \\
\hline \multicolumn{7}{|c|}{ unmarried HS grads age 20-34 } \\
\hline (3) black & 371 & 332 & 316 & 450 & 463 & 29 \\
\hline white & 546 & 466 & 554 & 666 & 583 & -171 \\
\hline \multicolumn{7}{|c|}{ married HS dropouts age 20-34 } \\
\hline (5) black & 30 & 32 & 23 & 35 & 25 & -1 \\
\hline white & 432 & 346 & 307 & 690 & 392 & -259 \\
\hline \multicolumn{7}{|c|}{ married HS graduates age 20-34 } \\
\hline (7) black & 252 & 233 & 200 & 303 & 306 & 36 \\
\hline white & 2,996 & 2,806 & 2,530 & 3,630 & 3,118 & -236 \\
\hline \multicolumn{7}{|l|}{ unmarried teens } \\
\hline black & 236 & 212 & 191 & 295 & 288 & 14 \\
\hline white & 380 & 318 & 378 & 480 & 408 & -132 \\
\hline \multicolumn{7}{|l|}{ married teens } \\
\hline (11) & 21 & 21 & 11 & 21 & 12 & 1 \\
\hline (12) white & 276 & 209 & 150 & 276 & 167 & -50 \\
\hline \multicolumn{7}{|c|}{$\begin{array}{l}\text { Sources: Vital Statistics Natality Data, Public-Use Data Files, years } 1989 \text { to } 1998 \text {, compiled by the U.S. National Center for } \\
\text { Health Statistics (NCHS); annual population estimates by state and age group are from the U.S. census bureau (figures are } \\
\text { not available by race.) } \\
\text { Notes: The set of "ever-treated" states includes the } 18 \text { states that eliminated additional cash benefits between } 1989 \text { and } 1998 \text {; } \\
\text { "post-family cap" is defined as six months after the implementation of the family cap policy. } \\
\text { The proportion of demographic group on welfare (not restricted to mothers), based on weighted means from the } 1989 \text { March } \\
\text { Current Population Survey: 1) } 61.9, \mathrm{n}=267 ; 2 \text { ) } 36.9, \mathrm{n}=820 ; 3) 22.0, \mathrm{n}=1,077 ; 4) 5.5, \mathrm{n}=5,843 ; 5) 12.9, \mathrm{n}=75 ; 6) 5.3 \text {, } \\
\mathrm{n}=1,129 ; 7) 2.7, \mathrm{n}=556 ; 8) 1.2, \mathrm{n}=8,240 ; 9) 8.77, \mathrm{n}=642 ; 10) 1.72, \mathrm{n}=4,394 ; 11) 40.4, \mathrm{n}=6 ; 12) 5.3, \mathrm{n}=203 \text {. }\end{array}$} \\
\hline
\end{tabular}




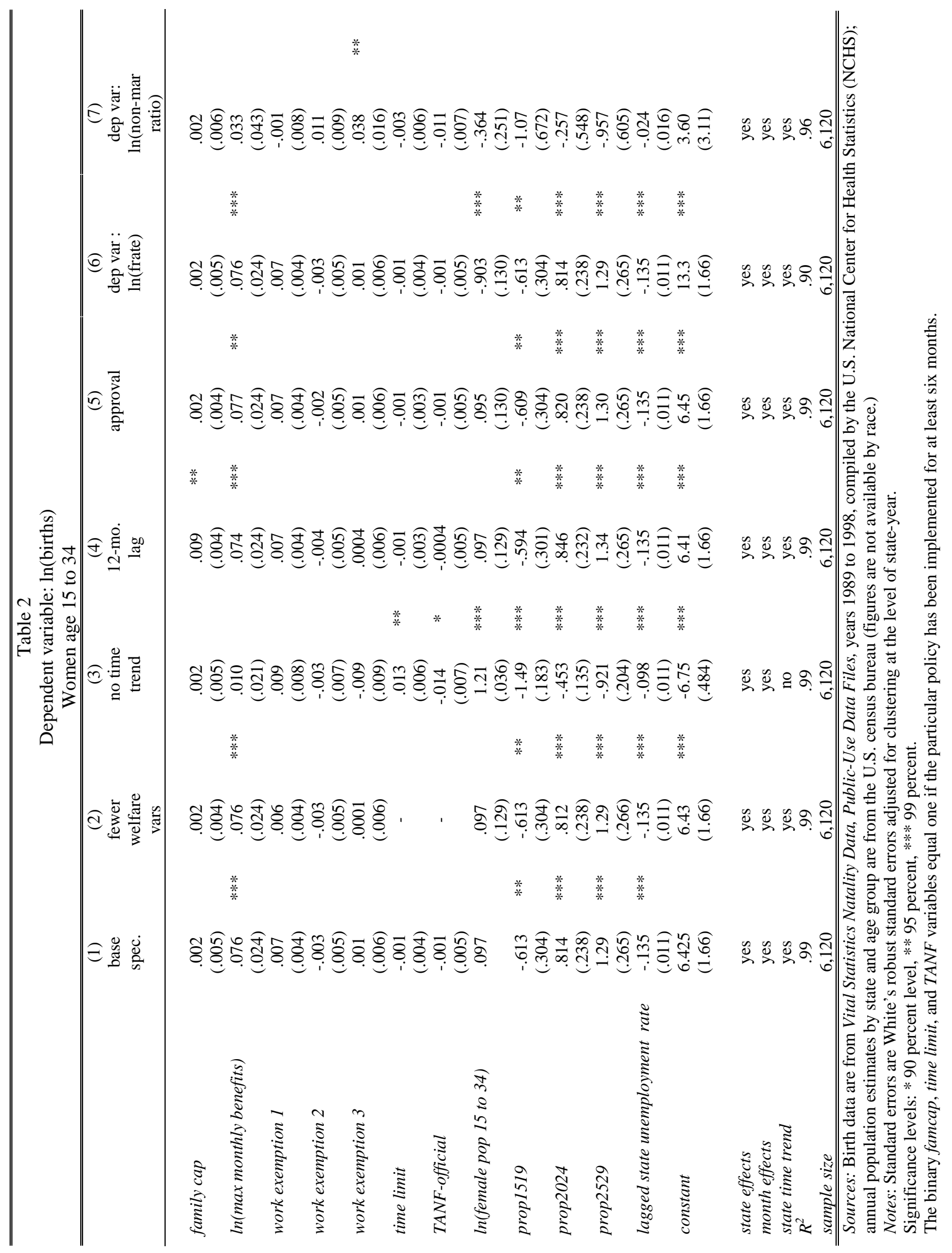




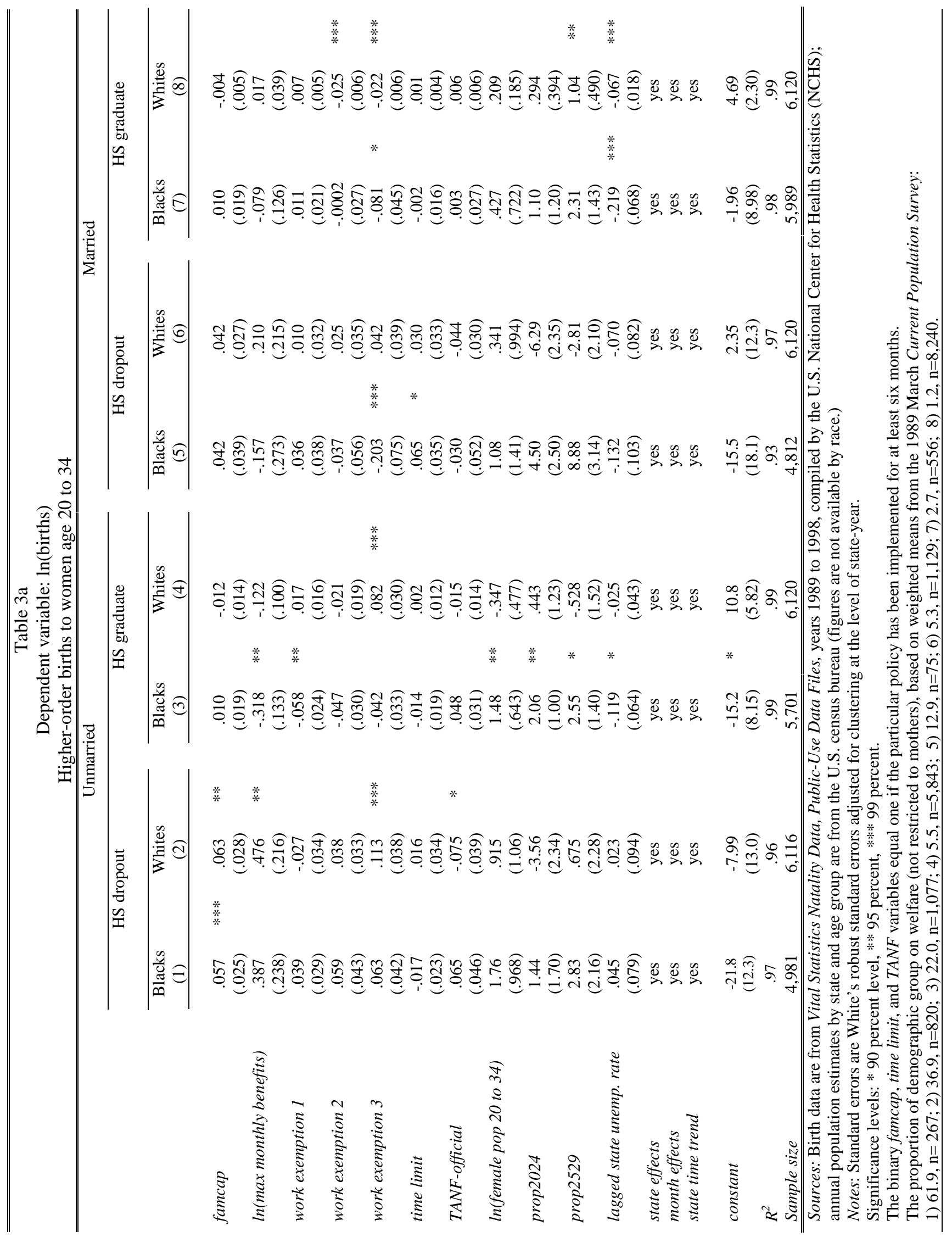




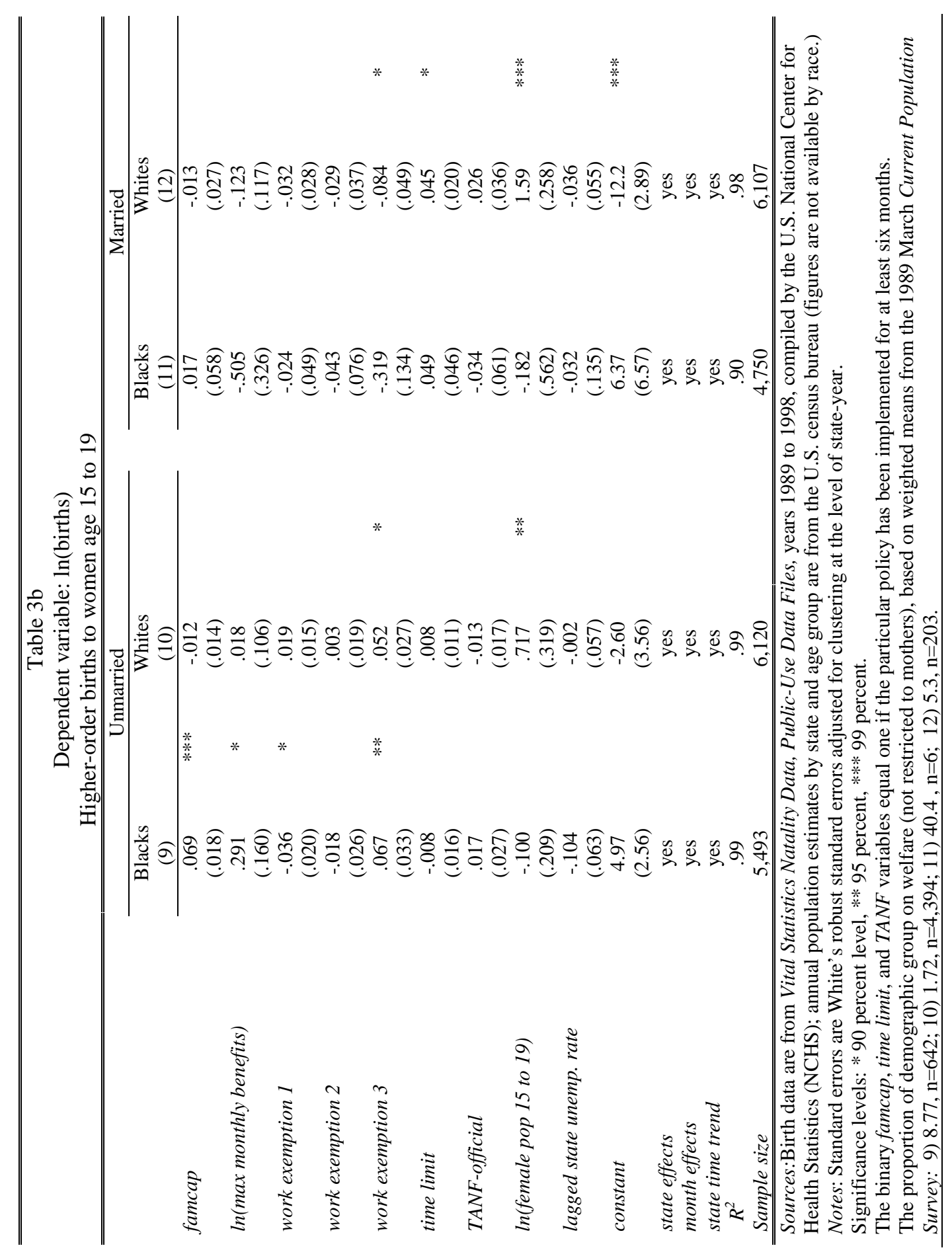




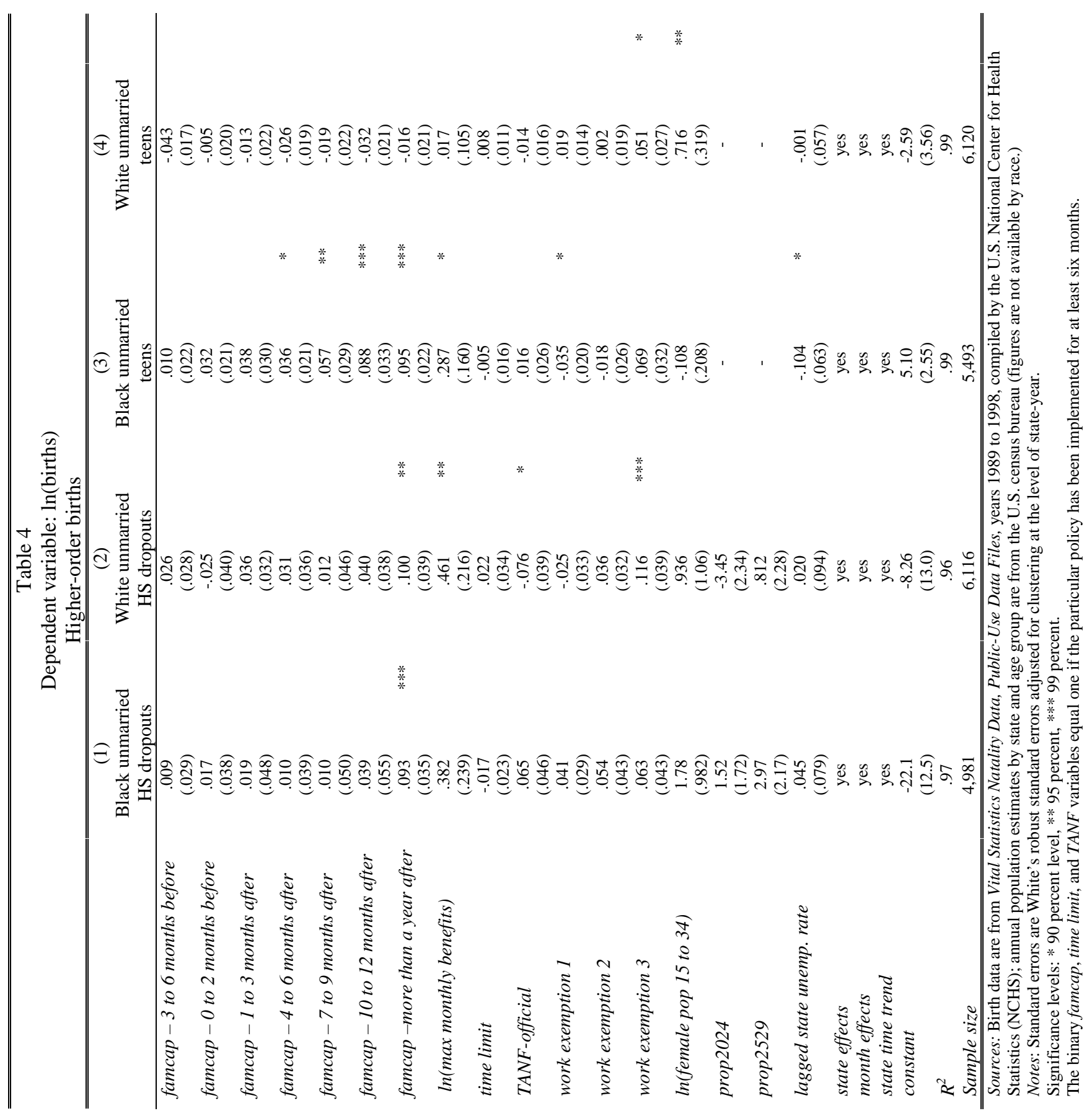


Appendix Table 1

State family cap policies

\begin{tabular}{|c|c|c|c|c|c|c|}
\hline & $\begin{array}{c}\text { Date } \\
\text { Implemented }\end{array}$ & $\begin{array}{c}\text { Date } \\
\text { Approved }\end{array}$ & $\begin{array}{c}\text { No } \\
\text { increase } \\
\text { in } \\
\text { assistance } \\
\text { for } \\
\text { add.child }\end{array}$ & $\begin{array}{l}\text { Partial } \\
\text { increase } \\
\text { in cash } \\
\text { assistance } \\
\text { for add. } \\
\text { child }\end{array}$ & $\begin{array}{l}\text { Increase in } \\
\text { assistance } \\
\text { for add. } \\
\text { child } \\
\text { provided as } \\
\text { voucher }\end{array}$ & $\begin{array}{l}\text { Increase in } \\
\text { cash } \\
\text { assistance } \\
\text { for add. } \\
\text { child to } \\
\text { third party }\end{array}$ \\
\hline Arizona & $11 / 95$ & $5 / 95$ & $\mathrm{X}$ & & & \\
\hline Arkansas & $7 / 94$ & $4 / 94$ & $X$ & & & \\
\hline California & $9 / 97$ & $8 / 96$ & $\mathrm{X}$ & & & \\
\hline Connecticut & $1 / 96$ & $12 / 95$ & & $\mathrm{X}$ & & \\
\hline Delaware & $10 / 95$ & $5 / 95$ & $\mathrm{X}$ & & & \\
\hline Florida & $10 / 96$ & $6 / 96$ & & $\mathrm{X}$ & & \\
\hline Georgia & $1 / 94$ & $11 / 93$ & $X$ & & & \\
\hline Idaho & $7 / 97$ & - & $\mathrm{X}$ & & & \\
\hline Illinois & $12 / 95$ & 9/95 & $X$ & & & \\
\hline Indiana & $5 / 95$ & $12 / 94$ & $\mathrm{X}$ & & & \\
\hline Maryland & $3 / 96$ & $8 / 95$ & & & & $X$ \\
\hline Massachusetts & $11 / 95$ & $8 / 95$ & $X$ & & & \\
\hline Mississippi & $10 / 95$ & $9 / 95$ & $\mathrm{X}$ & & & \\
\hline Nebraska & $11 / 95$ & $2 / 95$ & $X$ & & & \\
\hline New Jersey & $10 / 92$ & $7 / 92$ & $\mathrm{X}$ & & & \\
\hline North Carolina & $7 / 96$ & $2 / 96$ & $\mathrm{X}$ & & & \\
\hline North Dakota & $7 / 97$ & - & $X$ & & & \\
\hline Oklahoma & $10 / 96$ & - & & & $\mathrm{X}$ & \\
\hline South Carolina & $10 / 96$ & $5 / 96$ & & & $\mathrm{X}$ & \\
\hline Tennessee & $9 / 96$ & $7 / 96$ & $\mathrm{X}$ & & & \\
\hline Virginia & $7 / 95$ & $7 / 95$ & $\mathrm{X}$ & & & \\
\hline Wisconsin & $1 / 96$ & $6 / 94$ & $X$ & & & \\
\hline Wyoming & $1 / 97$ & - & $\mathrm{X}$ & & & \\
\hline
\end{tabular}

Source: Urban Institute (1998) summary of state TANF policies; Crouse (1999) - note these are the same dates used in the 1999 CEA report; Health and Human Services, Assistant Secretary for Planning and Evaluation, Setting the Baseline: A Report on State Welfare Waivers

Notes: Nineteen of the 23 states requested family cap waivers. Idaho, North Dakota, Oklahoma, and Wyoming implemented family caps as part of their TANF programs. 
Appendix Table 2

Welfare policy dates: AFDC waivers, TANF, and Time limits

\begin{tabular}{|c|c|c|c|c|c|}
\hline & \multicolumn{2}{|c|}{ AFDC waiver } & \multicolumn{2}{|c|}{ TANF implemented } & \multirow{2}{*}{$\begin{array}{c}\text { Time limit } \\
\text { implemented }\end{array}$} \\
\hline & Implemented & Approved & & Actual & \\
\hline Alabama & & & $12 / 96$ & & $12 / 96$ \\
\hline Alaska & & & $7 / 97$ & & $7 / 97$ \\
\hline Arizona & $11 / 95$ & $5 / 95$ & $11 / 95$ & & $11 / 95$ \\
\hline Arkansas & $7 / 94$ & $4 / 94$ & - & & - \\
\hline California & $12 / 92$ & $10 / 92$ & - & $1 / 98$ & - \\
\hline Colorado & 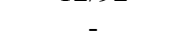 & - & $7 / 97$ & & $7 / 97$ \\
\hline Connecticut & $1 / 96$ & $8 / 94$ & $1 / 98$ & & $1 / 98$ \\
\hline Delaware & $10 / 95$ & $5 / 95$ & $7 / 97$ & & $7 / 97$ \\
\hline District of & - & - & $3 / 97$ & & $3 / 97$ \\
\hline \multicolumn{6}{|l|}{ Columbia } \\
\hline Florida & $10 / 96$ & $6 / 96$ & $2 / 94$ & & $2 / 94$ \\
\hline Georgia & $1 / 94$ & $11 / 93$ & $1 / 97$ & & $1 / 97$ \\
\hline Hawaii & $2 / 97$ & $6 / 94$ & $2 / 97$ & & $2 / 97$ \\
\hline Idaho & $7 / 97$ & $8 / 96$ & $7 / 97$ & & $7 / 97$ \\
\hline Illinois & $11 / 93$ & $11 / 93$ & $2 / 96$ & & $2 / 96$ \\
\hline Indiana & $5 / 95$ & $12 / 94$ & $5 / 95$ & & $5 / 95$ \\
\hline Iowa & $10 / 93$ & $8 / 93$ & $10 / 93$ & & $10 / 93$ \\
\hline Kansas & - & $8 / 96$ & $10 / 96$ & & $10 / 96$ \\
\hline Kentucky & - & - & $10 / 96$ & & $10 / 96$ \\
\hline Louisiana & - & $2 / 96$ & $1 / 97$ & & $1 / 97$ \\
\hline Maine & - & $6 / 96$ & $11 / 96$ & & $11 / 96$ \\
\hline Maryland & $3 / 96$ & $8 / 95$ & $1 / 97$ & & $1 / 97$ \\
\hline Massachusett & $11 / 95$ & $8 / 95$ & $12 / 96$ & & $12 / 96$ \\
\hline \multicolumn{6}{|l|}{$\mathrm{s}$} \\
\hline Michigan & $10 / 92$ & $8 / 92$ & -- & & -- \\
\hline Minnesota & - & - & 7/97 & & $7 / 97$ \\
\hline Mississippi & $10 / 95$ & $9 / 95$ & $10 / 96$ & $7 / 97$ & $10 / 96$ \\
\hline Missouri & $6 / 95$ & $4 / 95$ & $7 / 97$ & & $7 / 97$ \\
\hline Montana & $2 / 96$ & $4 / 95$ & $2 / 97$ & & $2 / 97$ \\
\hline Nebraska & $10 / 95$ & $2 / 95$ & $11 / 95$ & & $11 / 95$ \\
\hline Nevada & - & - & $12 / 96$ & & $12 / 96$ \\
\hline New & - & $6 / 96$ & $10 / 96$ & & $10 / 96$ \\
\hline \multicolumn{6}{|l|}{ Hampshire } \\
\hline New Jersey & $10 / 92$ & $7 / 92$ & $4 / 97$ & $7 / 97$ & $4 / 97$ \\
\hline New Mexico & - & - & $7 / 97$ & & $7 / 97$ \\
\hline New York & - & - & $12 / 96$ & $11 / 97$ & $12 / 96$ \\
\hline
\end{tabular}


Appendix Table 2 (cont'd)

Welfare policy dates: AFDC waivers, TANF, and Time limits

\begin{tabular}{|c|c|c|c|c|c|}
\hline & \multicolumn{2}{|c|}{ AFDC waiver } & \multicolumn{2}{|c|}{ TANF implemented } & \multirow{2}{*}{$\begin{array}{c}\text { Time limit } \\
\text { implemented }\end{array}$} \\
\hline & Implemented & Approved & Official & Actual & \\
\hline North & $7 / 96$ & 2/96 & $1 / 97$ & & 7/96 \\
\hline \multicolumn{6}{|l|}{ Carolina } \\
\hline North & - & - & $7 / 97$ & & 7/97 \\
\hline \multicolumn{6}{|l|}{ Dakota } \\
\hline Ohio & $7 / 96$ & $3 / 96$ & $10 / 96$ & & $10 / 97$ \\
\hline Oklahoma & - & - & $10 / 96$ & & $10 / 96$ \\
\hline Oregon & $2 / 93$ & $7 / 92$ & $10 / 96$ & & $7 / 96$ \\
\hline Pennsylvania & - & - & $3 / 97$ & & 3/97 \\
\hline Rhode Island & - & - & $5 / 97$ & & $5 / 97$ \\
\hline South & - & $5 / 96$ & $10 / 96$ & & $10 / 96$ \\
\hline \multicolumn{6}{|l|}{ Carolina } \\
\hline South & $6 / 94$ & $3 / 94$ & $12 / 96$ & & $12 / 96$ \\
\hline \multicolumn{6}{|l|}{ Dakota } \\
\hline Tennessee & 9/96 & $7 / 96$ & $10 / 96$ & & $10 / 96$ \\
\hline Texas & $6 / 96$ & $3 / 96$ & $11 / 96$ & & $6 / 96$ \\
\hline Utah & $1 / 93$ & $12 / 92$ & $10 / 96$ & & $1 / 97$ \\
\hline Vermont & $7 / 94$ & $4 / 93$ & $9 / 96$ & & -- \\
\hline Virginia & $7 / 95$ & $7 / 95$ & $2 / 97$ & & $7 / 95$ \\
\hline Washington & $1 / 96$ & $9 / 95$ & $1 / 97$ & & $8 / 97$ \\
\hline West & $2 / 96$ & $7 / 95$ & $1 / 97$ & & $1 / 97$ \\
\hline \multicolumn{6}{|l|}{ Virginia } \\
\hline Wisconsin & $1 / 96$ & $6 / 94$ & 9/96 & 9/97 & $10 / 96$ \\
\hline Wyoming & - & - & $1 / 97$ & & $1 / 97$ \\
\hline Total & & 34 & & & 47 \\
\hline
\end{tabular}

Sources: Crouse (1999) - note these are the same dates used in the 1999 CEA report; Health and Human Services, Assistant Secretary for Planning and Evaluation, Setting the Baseline: A Report on State Welfare Waivers; Urban Institute (1998) summary of state TANF policies. 
Appendix Table 3

Caretaker Work Exemption Policies,

Date of Implementation by Age of Youngest Child

\begin{tabular}{|c|c|c|c|c|c|c|}
\hline & $\begin{array}{c}\text { No } \\
\text { exemption }\end{array}$ & $\begin{array}{l}\text { Date } \\
\text { implemented } \\
\text { (Waiver or } \\
\text { TANF) } \\
\end{array}$ & $\begin{array}{l}\text { Up to and } \\
\text { including } \\
6 \text { mos. }\end{array}$ & $\begin{array}{l}\text { Date } \\
\text { implemented } \\
\text { (Waiver or } \\
\text { TANF) } \\
\end{array}$ & $\begin{array}{l}\text { Over } 6 \\
\text { months }\end{array}$ & $\begin{array}{l}\text { Date } \\
\text { implemented } \\
\text { (Waiver or } \\
\text { TANF) } \\
\end{array}$ \\
\hline Alabama & & & & & 1 year & $11 / 96(\mathrm{~T})$ \\
\hline Alaska & & & & & 1 yaer & $7 / 97(\mathrm{~T})$ \\
\hline Arizona & & & & & 1 year & $10 / 96(\mathrm{~T})$ \\
\hline Arkansas & & & $3 \mathrm{mos}$ & 7/97 (T) & & \\
\hline California & & & $6 \mathrm{mos}$ & $1 / 98(\mathrm{~T})$ & & \\
\hline Colorado & county option & (T) & & & & \\
\hline Connecticut & & & & & 1 year & $10 / 96(\mathrm{~T})$ \\
\hline Delaware & & & 13 weeks & 3/97 (T) & & \\
\hline D.C. & & & 1 year & $3 / 97(\mathrm{~T})$ & & \\
\hline Florida & & & $3 \mathrm{mos}$ & $10 / 96(\mathrm{~T})$ & & \\
\hline Georgia & no ex. & $1 / 97(\mathrm{~T})$ & & & & \\
\hline Hawaii & & & $6 \mathrm{mos}$ & 2/97 (W) & & \\
\hline Idaho & no ex. & 7/97 (T) & & & & \\
\hline Illinois & & & & & 1 year & 7/97 (T) \\
\hline Indiana $^{1}$ & & & & & 1 year & $10 / 96(\mathrm{~T})$ \\
\hline Iowa & no ex. & $1 / 97(\mathrm{~T})$ & $3 \mathrm{mos}$ & $10 / 93(\mathrm{~W})$ & & \\
\hline Kansas & & & & & 1 year & $10 / 96(\mathrm{~T})$ \\
\hline Kentucky & & & & & 1 year & $10 / 96(\mathrm{~T})$ \\
\hline Louisiana & & & & & 1 year & $1 / 97(\mathrm{~T})$ \\
\hline Maine & & & & & 1 year & $11 / 96(\mathrm{~T})$ \\
\hline Maryland & & & 12 weeks & 10/96 (W) & 1 year & $12 / 96(\mathrm{~T})$ \\
\hline Massachusetts & & & $6 \mathrm{mos}$ & $9 / 96(\mathrm{~T})$ & & \\
\hline Michigan & no ex. & $10 / 94(W)$ & $3 \mathrm{mos}$ & $9 / 96(\mathrm{~T})$ & & \\
\hline Minnesota & & & & & 1 year & 9/97 (T) \\
\hline Mississippi & & & & & 1 year & 9/97 (T) \\
\hline Missouri & & & & & 1 year & $12 / 96(\mathrm{~T})$ \\
\hline Montana & no ex. & 2/97 (W) & & & & \\
\hline Nebraska & & & $\begin{array}{c}12 \text { weeks } \\
3 \text { mos }\end{array}$ & $\begin{array}{l}3 / 96(\mathrm{~W}) \\
7 / 97(\mathrm{~T})\end{array}$ & 1 year & $12 / 96(\mathrm{~T})$ \\
\hline Nevada & & & & & 1 year & $12 / 96(\mathrm{~T})$ \\
\hline New & & & & & 3 years & (T) \\
\hline Hampshire & & & & & & \\
\hline New Jersey & & & 12 weeks & 7/97 (T) & 2 years & $10 / 92(W)$ \\
\hline New Mexico & & & & & 1 year & 7/97 (T) \\
\hline New York & & & & & 1 year & $11 / 97(\mathrm{~T})$ \\
\hline
\end{tabular}


Appendix Table 3 (cont'd)

Caretaker Work Exemption Policies,

Age of Youngest Child and Date of Implementation

\begin{tabular}{|c|c|c|c|c|c|c|}
\hline & $\begin{array}{c}\text { No } \\
\text { exemption }\end{array}$ & $\begin{array}{l}\text { Date } \\
\text { implemented } \\
\text { (Waiver or } \\
\text { TANF) }\end{array}$ & $\begin{array}{l}\text { Up to and } \\
\text { including } \\
6 \text { mos. }\end{array}$ & $\begin{array}{l}\text { Date } \\
\text { implemented } \\
\text { (Waiver or } \\
\text { TANF) }\end{array}$ & $\begin{array}{l}\text { Over } 6 \\
\text { months }\end{array}$ & $\begin{array}{l}\text { Date } \\
\text { implemented } \\
\text { (Waiver or } \\
\text { TANF) }\end{array}$ \\
\hline North & & & & & 5 years & 7/96 (W) \\
\hline Carolina & & & & & 1 year & $1 / 97(\mathrm{~W})$ \\
\hline North & & & $3 \mathrm{mos}$ & 7/97 (T) & & \\
\hline \multicolumn{7}{|l|}{ Dakota } \\
\hline Ohio & & & & & 1 year & $10 / 96(\mathrm{~T})$ \\
\hline Oklahoma & & & & & 1 year & $10 / 96(\mathrm{~T})$ \\
\hline Oregon & & & $3 \mathrm{mos}$ & 2/93 (W) & & \\
\hline Pennsylvania & & & & & 1 year & 3/97 (T) \\
\hline Rhode Island & & & & & 1 year & $5 / 97(\mathrm{~T})$ \\
\hline South & & & & & 1 year & $10 / 96(\mathrm{~T})$ \\
\hline \multicolumn{7}{|l|}{ Carolina } \\
\hline South & & & 12 weeks & $12 / 96(\mathrm{~T})$ & & \\
\hline \multicolumn{7}{|l|}{ Dakota } \\
\hline Tennessee & & & 16 weeks & 9/96 (W) & & \\
\hline Texas & & & & & 4 years & $?$ \\
\hline Utah & no ex. & $10 / 96(\mathrm{~T})$ & & & & \\
\hline Vermont & & & 16 weeks & 7/94 (W) & $18 \mathrm{mos}$ & 9/96 (T) \\
\hline Virginia & & & & & $18 \mathrm{mos}$ & $10 / 97(\mathrm{~T})$ \\
\hline Washington & & & & & 1 year & $1 / 97(\mathrm{~T})$ \\
\hline West & & & & & 1 year & $1 / 97(\mathrm{~T})$ \\
\hline \multicolumn{7}{|l|}{ Virginia } \\
\hline Wisconsin & & & 12 weeks & 9/97 (T) & 1 year & 1/96 (W) \\
\hline Wyoming & & & 3 months & $1 / 97(\mathrm{~T})$ & & \\
\hline Total & & & & & & \\
\hline
\end{tabular}

Notes: Under TANF, 26 states exempt a mother while the youngest child is under 1 year of age; Vermont and Virginia allow an exemption up to 18 months; Texas is the only state to have a higher age limit, set at 4 years, but the exemption may only be used once for each family.

1. Indiana law only allows exemptions for care of a child under 12 weeks if child is conceived while family is on aid. Sources: Crouse (1999) - note these are the same dates used in the 1999 CEA report; Health and Human Services, Assistant Secretary for Planning and Evaluation, Setting the Baseline: A Report on State Welfare Waivers; Urban Institute (1998) summary of state TANF policies. 


\section{References}

Acs, Gregory. 1994. “The impact of AFDC on young women's childbearing decisions.” Washington, D.C.: Urban Institute.

Acs, Gregory. 1996. "The impact of welfare on young mother's subsequent childbearing decisions." Journal of Human Resources 31(4): 898-915.

An, Chong Bum, Robert Haveman, and Barbara Wolfe. 1993. "Teen out-of-wedlock births and welfare receipt: The role of childhood events and economic circumstance." Review of Economics and Statistics 75(2): 195-208.

Argys, Laura M. and Daniel I. Rees. 1996. "The Impact of Welfare Generosity on the Fertility Behavior of Recipients," University of Colorado at Denver, Center for Research on Economic and Social Policy working paper 9601.

Becker, Gary. 1981. A Treatise on the Family. Cambridge: Harvard University Press.

Bertrand, Marianne, Esther Duflo, and Sendhil Mullainathan. 2002. "How Much Should We Trust Differencesin-Differences Estimates?” NBER working paper 7627. Cambridge, MA, March.

Bronars, Stephen G. and Jeff Grogger. 1994. "The Economic Consequences of Unwed Motherhood: Using Twin Births as a Natural Experiment.” American Economic Review 84(5): 1141-1156.

Camasso, Michael, Carol Harvey, Radha Jagannathan, and Mark Killingsworth. 1999. “New Jersey’s Family Cap and Family Size Decisions: Some Findings from a 5-Year Evaluation." Rutgers University.

Crouse, Gil 1999. “State Implementation of Major Changes to Welfare Policies, 1992-1998.” Office of Human Services Policy, Assistant Secretary for Planning and Evaluation, U.S. Department of Health and Human Services. www.aspe.hhs.gov/hsp/Waiver-Policies99/policy_CEA.htm

Council of Economic Advisors. 1999. “Technical Report: Economic Expansion, Welfare Reform, and the Decline in Welfare Caseloads: An Update" Executive Office of the President of the United States.

Danziger, Sheldon, Robert Haveman, and Robert Plotnick 1981. "How Income Transfers Affect Work, Savings, and The Income Distribution: A Critical Review." Journal of Economic Literature 19(3): 975-1028.

Duncan, Greg J. and Saul D. Hoffman 1990. "Welfare Benefits, Economic Opportunities and Out-of-Wedlock Births Among Black Teenage Girls.” Demography 27: 519-535.

Ellwood, David and Mary Jo Bane. 1985. "The Impact of AFDC on Family Structure and Living Arrangements.” In R. Ehrenberg (ed.), Research in Labor Economics 7: 137-207.

Fairlie, Robert W. and Rebecca A. London. 1997. "The Effect of Incremental Benefit Levels on Births to AFDC Recipients.” Journal of Policy Analysis and Management 16: 575-597.

Gallagher, L. Jerome, Megan Gallagher, Kevin Perese, Susan Schreiber, and Keith Watson. 1998. “One Year after Federal Welfare Reform: A Description of State Temporary Assistance for Needy Families 
(TANF) Decisions as of October 1997." Washington D.C.: Urban Institute, Occasional Paper Number 6. http://newfederalism.urban.org/html/occas6.htm.

Green Book. 1998. "Section 7: Aid to Families with Dependent Children and Temporary Assistance for Needy families." Ways and Means Committee, from the U.S. Government Printing Office Online via GPO Access. http://frwebgate.access.gpo.gov.

Hoffman, Saul D. and E. Michael Foster. 2000. "AFDC Benefits and Nonmarital Births to Young Women." Journal of Human Resources 35 (2): 376-391.

Horvath-Rose, Anne and H. Elizabeth Peters. 2000. "Welfare Waivers and Nonmarital Childbearing." Joint Center for Poverty Research working paper 128. January.

Hoynes, Hillary. 1997. “Does Welfare play any role in female headship decisions?” Journal of Public Economics 65(2), 89-117.

Levine, Phillip B. and D.J. Zimmerman. 1999. "An Empirical Analysis of the Welfare Magnet Debate." Journal of Population Economics 12(3): 391-409.

Loury, Glenn C. 2000. "Preventing Subsequent Births to Welfare Recipients," in Douglas J. Besharov and Peter Germanis, eds, Preventing Subsequent Births to Welfare Recipients. College Park, Maryland: School of Public Affairs.

Lundberg, Shelly and Robert Plotnick. 1990. "Effects of State Welfare, Abortion, and Family Planning Policies on Premarital Childbearing Among White Adolescents." Family Planning Perspectives 29 (2): 52-60.

Lundberg, Shelly and Robert Plotnick. 1995. “Adolescent premarital childbearing: Do economic incentives matter?" Journal of Labor Economics 13 (2): 177-200.

Moffitt, Robert. 1992. "Incentive Effects of the U.S. Welfare System: A Review." Journal of Economic Literature 30: 1- 61.

Moffitt, Robert. 1994. "Welfare effects on female headship with area effects.” Journal of Human Resources 29 (2): 621-636.

Moffitt, Robert. 1998. "The Effect of Welfare on Marriage and Fertility," in Robert Moffitt, ed. Welfare, the Family, and Reproductive Behavior. Washington, D.C.: National Academy Press.

Robins, Philip K. and Paul Fronstin. 1996. "Welfare Benefits and Birth Decisions of Never-Married Women." Population Research and Policy Review 15: 21-43.

Rosenzweig, Mark R. 1999. "Welfare, Marital Prospects, and Non-marital Childbearing." Journal of Political Economy 107 (6): S3-32.

Schettini, Melissa. 2000. "Is There an Effect of Incremental Welfare Benefits on Fertility Behavior? A Look at the Family Cap.” MIT Department of Economics, unpublished mimeo, August.

Schoeni, Robert F. and Rebecca M. Blank. 2000. "What has welfare reform accomplished? Impacts on welfare participation, employment, income, poverty, and family structure.” NBER working paper 7627. Cambridge, MA, March. 
"Setting the Baseline: A Report on State Welfare Waivers". 1997. Office of the Assistant Secretary for Planning and Evaluations, U.S. Department of Health and Human Services.

http://aspe.hhs.gov/hsp/isp/wavier2/title.htm.

Turturro, Carolyn, Brent Benda, and Howard Turney. 1997. Arkansas Welfare Waiver Demonstration Project, Final Report (July 1994 through June 1997). University of Arkansas at Little Rock, School of Social Work.

Ziliak, James P., David N. Figlio, Elizabeth E. Davis, and Laura S. Connolly. 2000. "Accounting for the Decline in AFDC Caseloads.” Journal of Human Resources 35(3): 570-586. 